\author{
ANNA ANTONINA NOGAJ \\ IZABELA CZARNECKA \\ ROMAN OSSOWSKI
}

Kazimierz Wielki University in Bydgoszcz, Poland

Faculty of Psychology

\title{
DIFFERENCES IN THE STRESS COPING STYLES AND SOCIAL SKILLS BETWEEN CLASSICAL AND JAZZ MUSICIANS
}

The musical milieu raises a number of challenges for artists. Coping with these depends not only on the level of musical abilities but also on a number of personal skills. The diverse styles of music education and the expectations set for musicians performing various music genres have inspired research exploring the differences between classical and jazz musicians. Of the psychological areas important for functioning effectively as a musician, stress management styles and social skills have been examined in this study. It was assumed that the genre of publicly performed music, and thus the different modes of music education in the field of classical and jazz music performance, can cause significant differences in the psychological functioning of musicians. Of the 73 musicians who participated in the study, 38 were classical musicians and 35 were jazz musicians. The jazz musicians revealed a significantly higher level of social competence in terms of social exposure compared to the classical musicians. There were no differences in the style of coping with stress between the two groups. The results of the study might inspire psychologists working with musicians to plan therapeutic programs aimed at psychological preparation for public performances, with the specificity of musical genres taken into account. Future research may investigate the extent temperament and personality of musicians representing different specialties influence their stress coping strategies and social skills.

Keywords: stress coping styles; social skills; classical musicians; jazz musicians.

Corresponding author: Correspondence concerning this article should be addressed to ANNA NogAJ-Kazimierz Wielki University in Bydgoszcz, Faculty of Psychology, ul. J. K. Chodkiewicza 30, 85-064 Bydgoszcz, Poland; e-mail address: nogaj@ukw.edu.pl 


\section{INTRODUCTION}

The psychological functioning of musicians may be partly determined by the musical genres they perform (see Perdomo-Guevara, 2014). Common experiences, resulting from music education or from the form of public performances, create similar psychological conditions, which translate into the dominant personality traits or behaviors (see Davidson, 2009). This means that musicians playing different genres of music, or musicians with different instrumental specialties, can significantly differ from one another (Kemp, 1996).

Professional musical performance, regardless of the genre, demands high standards; consequently, it requires both the ability to cope with both the pressure resulting from the rigors of everyday work and strong resistance to stress involved in public exposure. The key to success in musical performance lies not only in the artist's musical abilities but in a whole range of psychophysical conditions (Manturzewska, 2014). The ability to manage stress in difficult situations and a high level of social skills are preconditions of high musical achievement and success in musical performance (see Brackett, Mayer, \& Warner, 2004; McPherson \& Schubert, 2004; Stoeber \& Eismann, 2007).

Both classical music and jazz are genres that require particularly high executive competence from professional musicians (Lehmann, Sloboda, \& Woody, 2007). However, the artistic requirements are different for classical and jazz musicians. Classical music performances are based on perfect score reproduction, faithful to the composer's intention. In the case of jazz, it is improvisation that prevails; this requires autonomous musical ideas and subjectivity inspired by the theme of a musical piece (see Bézenak \& Swindells, 2009).

The aim of this study was to find out if there are differences between musicians studying classical and jazz music in terms of stress coping styles and social skills.

\section{Musicians' Coping With Stress and the Level of Social Skills}

The phenomenon of stress is quite often analyzed in the psychology of music, both from practical and theoretical perspectives. This is evidenced by numerous works devoted to the performance anxiety experienced by musicians as well as publications on the strategies of dealing with stage fright (Williamon, 2004; Klickstein, 2009; Kenny, 2011; Bissinger-Ćwierz \& Nogaj, 2018; KantorMartynuska \& Domaradzka, 2018). Musicians' way of responding to stress in the 
context of public performances is therefore a key issue. Coping with stress, including stage fright, is also one of the basic skills a musician should have. The relations between effective stress coping styles, high self-efficacy, and artistic achievements have been demonstrated (see McPherson \& Schubert, 2004; Stoeber \& Eismann, 2007; Kenny, 2011).

Coping with stress is a cognitive and behavioral ability to meet specific requirements in difficult situations (Lazarus \& Folkman, 1984). A person's general functioning in life and professional achievements in music are often indirectly dependent on their skills and coping style (see Manturzewska, 2014). One of the classifications of stress coping styles (Parker \& Endler, 1992) distinguishes: (1) task-focused style (a tendency to make efforts to solve the problem through cognitive actions or attempts to change the situation), (2) emotion-focused style (found in people who focus on themselves and on their own emotional experiences in stressful situations), and (3) avoidance-focused style (diverting attention from a difficult situation through alternative activities or looking for social contacts). The emotion-focused and avoidance-focused styles are less effective than the task-focused style.

The education and profession of a musician constantly requires the artist to cope with stress, mainly in the context of public performances (Steptoe, 1989). This condition facilitates or hinders functioning at the physiological, behavioral, and cognitive levels when preparing for a concert, during the performance, and even after leaving the stage (see Steptoe, 2001; Kenny, 2011; Kantor-Martynuska \& Domaradzka, 2018).

Unlike stress, musicians' social competence is rarely examined in music psychology (Nogaj, 2018). However, in educational practice, social skills are one of the three pillars of professional qualifications that should be provided by the Polish education system at every level (Chłon-Domińczak, Sławiński, Kraśniewski, \& Chmielecka, 2017). In the context of music education, social skills are closely related to students' functioning in the master-student relationship (JaślarWalicka, 1999; Hallam, 2008; Welch \& Ockelford, 2009) and to preparation for public performances (Williamon, 2004; Altenmüller \& Furuya, 2016).

A high level of social skills promotes efficient functioning in social situations (Argyle, 1991; Matczak, 2001a). Among the numerous classifications of social skills (see Martowska, 2012), the one proposed by Matczak (2001b) deserves special attention. The author distinguished skills that determine behavioral effectiveness in: (1) intimate situations, (2) social exposure situations, and (3) situations requiring assertiveness. 
Musicians are expected to have high social competence, which, along with musical abilities and cognitive, personality, and emotional conditioning, is an integral part of their functioning (see Kemp, 1996; Gaunt \& Hallam, 2009; Manturzewska, 2014). The social competence of musicians, however, develops not only in the context of public performances, but above all as through various social interactions, especially the music student's relationship with the master introducing him of her to the secrets of musical art (Jaślar-Walicka, 1999; Welch \& Ockelford, 2009). Musicians' high social competence is also demonstrated by their nonverbal communication skills, which are necessary for effective communication between musicians during performances (Davidson, 2007).

The level of social skills, especially those related to public exposure, can be the main determinant of academic achievement (Brackett, Mayer \& Warner, 2004) and success in professional career (Smółka, 2016). Musicians' social skills develop in various directions from the beginning of their musical education. From the level of arts education, young entrants to the musical art are required to have cooperation skills in individual teaching relationships, readiness for public performances, and resistance to peer competition (see Nogaj, 2018).

Before answering the question of whether the styles of coping with stress and social skills differ significantly between classical and jazz musicians, let us discuss the differences in their functioning associated with the specificity of their education and the nature of their public performances.

\section{Differences in Education and Performance Between Classical and Jazz Musicians}

Without a doubt, in a historical context, professional education has stronger roots in the field of classical music than in jazz. ${ }^{1}$ In Poland, the development of music education has contributed to shaping high classical music performance skills among children and youth over the last two hundred years (see Jankowski, 2002). Jazz education, by contrast, only reached Poland in the second half of the twentieth century. Jazz was initially taught informally, as part of workshops or courses offered by selected cultural centers (see Białkowski, 2013). In the 1990s, the first music schools were established in several Polish cities. While these

\footnotetext{
${ }^{1}$ The article compares music education systems in Poland, where jazz is not as popular as in the United States and where there is no comparable tradition of popular music making. Moreover, in Polish culture, there is no common music tradition based on improvisation, which in the United States has developed in the African American community (see Berliner, 1994; Wilson \& MacDonald, 2005; Białkowski, 2013).
} 
schools were mainly private, they granted young people access to formal education in the field of jazz (see Lemański, 2013). As a result, the vast majority of jazz musicians in Poland (and in other parts of Europe) have developed their musical skills based on formal education in the field of classical music. It is likely that formal jazz education takes less time than classical education because the teaching of specialized jazz subjects start later (Creech et al., 2008). However, in the jazz tradition, whose sources are in the black community of African Americans, musicians more often emerge spontaneously, without formal music education (Berliner, 1994).

Formal music education in jazz has made it possible to identify certain general rules that govern improvisation and to maintain specific educational and executive standards. It is therefore possible to get to know the functioning of musicians of various musical specialties and genres (for example: classical music, jazz, blues, or pop music) and to identify differences between them, which have not only a cognitive dimension but also a number of practical implications for education (see Białkowski, 2013).

The identity of a jazz musician is the effect of understanding not only the context of the improvisation-based performance itself, but also the social context of functioning in a group of musicians (MacDonald \& Wilson, 2005; Mac-Donald, Hargreaves, \& Miell, 2009). In other words, jazz education involves not only mastering the knowledge and improvisation skills of the so-called "masterful"/“classical" jazz repertoire, but also willingness to create a unique "mystery" repertoire, relying on one's own musical instinct (Wilson \& MacDonald, 2005).

Regardless of the type of musical education, the differences in the functioning of classical and jazz musicians are mainly due to the completely different styles of their musical performance. A performance by classical musicians requires precise reproduction of specific musical notes or phrases while capturing and emotionally conveying the composer's intentions (Lehmann et al., 2007). A jazz performance is expected to express the message of the song as it is felt and understood by the performing artist. Jazz musicians' performances require the ability to improvise, which — to a large extent-results from ongoing, independent, creative decisions related to the development of a specific musical theme (see Kenny \& Gellrich, 2002).

When comparing the work style of classical musicians with the style of those who specialize in other music genres (including jazz and blues), some characteristic differences are noticeable. For classical musicians, it is important to devote plenty of time to practicing and listening to classical music (Creech et al., 2008). 
For non-classical musicians, it is important to make music in informal groups and to play just for fun.

However, after reaching the appropriate level of performance skills and musical maturity, people whose artistic expression tends to take the form of improvisation consciously seek teachers or masters who have developed jazz education paths before them. If one compares improvisation to spontaneous speech in the mother tongue (Johnson-Laird, 2002) and the reconstructing game of classical musicians to an actor's speech, one will start to wonder whether classical and jazz musicians still differ-and if so, in terms of what characteristics or skills they differ. This is mainly related to the fact that in the performance of jazz music, apart from the musician's ability to improvise, more attention is paid to the value of social interaction between musicians who share a common artistic goal (Bastien \& Hostager, 1988). The differences in education and performance style between classical and jazz musicians inspired a deeper understanding of the specifics of their functioning.

\section{Psychosocial Differences Between Classical and Jazz Musicians}

The analysis of the selected literature indicates specific differences in psychosocial functioning between musicians representing various musical genres. Jazz musicians exhibit lower stress experience than classical musicians (Papageorgi, Creech, \& Welch, 2013). They also show higher openness to experience (understood as a personality trait), greater ability to think creatively (Benedek, Borovnjak, Neubauer, \& Kruse-Weber, 2014), and more independence during musical performance, allowing themselves to express their own personality on stage (Dobson, 2010).

Classical musicians, by contrast, are more faithful to the composer's message as well as the conductor's requirements (Parasuraman \& Purohit, 2000; Dobson, 2010) and enter the roles assigned to them very precisely (Auslander, 2006). The focus on performance precision may lead to high stress (Kenny, 2011). Classical musicians display the highest level of stress associated with public exposure compared to jazz musicians and popular music performers (Papageorgi et al., 2013); they experience fewer positive and more negative performance-related emotions than non-classical performers (Perdomo-Guevara, 2014).

The main aim of the study was to explore the differences between musicians educated in the fields of classical and jazz music in terms of their styles of coping with stress (task-, emotion-, and avoidance-focused styles) and social skills 
(in intimate, exposure, and assertiveness situations). These variables are not commonly investigated in the psychology of music, although they concern the emotional and social spheres of human functioning, which are as important as executive skills for high artistic achievements (see Manturzewska, 2014).

Previous research has shown that jazz musicians stand out with a lower level of stress and tend to be more open to new experiences than classical musicians (Papageorgi et al., 2013; Benedek et al., 2014). As lower level of stress is associated with higher use of effective coping strategies and lower use of less effective ones (Parker \& Endler, 1992), jazz musicians may show a higher level of taskfocused coping style as well as a lower level of emotion-focused and avoidancefocused styles when compared to classical musicians. Also, given the lower performance anxiety in jazz versus classical musicians, the former may exhibit better skills in the area of social exposure, which allow them to better cope with stress in situations such as public performances.

\section{METHOD}

\section{Sample}

The sample consisted of 73 students from the Music Academy in Bydgoszcz, Poland; 38 of them were studying classical music in the Instrumental Department and 35 were studying jazz in the Department of Conducting, Jazz, and Music Education. In each tested group there were people playing various instruments (i.e., strings, keyboards, woodwind, percussion).

The age of the surveyed students ranged from 18 to 28 years $(M=21.25$, $S D=1.94)$. In the group of classical musicians, the age ranged between 18 and 28 years $(M=20.5, S D=1.9)$. In the group of jazz musicians, the age ranged between 20 and 25 years $(M=22.06, S D=1.66)$. A $t$-test analysis showed that there was a significant age difference between the groups of classical and jazz musicians, the former being significantly younger than the latter, $t(73)=-3.71$, $p<.001$.

There were 27 women (37\%) and 46 men (63\%) in the sample. In the group of classical musicians there were 20 men $(53 \%)$ and 18 women $(47 \%)$, while in the group of jazz musicians there were 26 men (74\%) and 9 women (26\%). There was a significant difference in gender proportions between the two groups, with significantly more men than women among jazz musicians, $\chi^{2}(1, N=73)=3.66$, $p \leq .05$. 
In the group of jazz musicians, 33 participants declared that they had received at least six years of education in classical music.

\section{Measures}

In order to assess stress coping strategies, we used the Polish adaptation of the Coping Inventory for Stressful Situations Questionnaire (CISS; Endler \& Parker, 1990; Strelau, Jaworowska, Wrześniewski, \& Szczepaniak, 2005). To measure social skills, we used the Social Competences Questionnaire (SCQ) by Matczak (2007).

The CISS self-report questionnaire consists of 48 items concerning various human behaviors in stressful situations. Answers are given on a 5-point Likert scale, ranging from 1 - not at all to 5 - very much. Respondents rate the extent to which they engage in the activities listed when encountering stressful situations. The questions are divided into three scales with 16-items in each, corresponding to different strategies or styles of coping with stress: (1) Task-Focused Style (TFS) - defines the tendency to make efforts to solve the problem through cognitive actions or attempts to change the situation; (2) emotion-focused style (EFS) - refers to emotional responses focused on self-oriented reactions aimed at reducing the internal tension associated with the stressful situation; (3) avoidance-focused style (AFS) - refers to activities and cognitive changes aimed at avoiding the stressful situation either through distraction (D), which consists in getting involved in alternative activities, e.g., watching television, eating, or thinking about pleasant things, or through social diversion (SD), which consists in initiating social contacts. The AFS scale consists of two subscales: an 8-item AFS-D subscale and a 5-item AFS-SD subscale. Scores for all items per scale are summed to form scale scores; higher scores indicate a stronger tendency to use of a particular coping strategy (Brands, Köhler, Stapert, Wade, \& van Heugten, 2014). The possible range of scores is $16-80$ for the TFS, EFS, and AFS scales, 8-40, for the AFS-D scale, and 5-25 for the AFS-SD scale.

The reliability of the measure (Cronbach's $\alpha$ ) can be considered acceptable (Strelau et al., 2005). For the TFS and EFS scales, $\alpha$ ranged from .82 to .88 , and for the AFS scale its value was .74 to .78 (except for the SD subscale, whose reliability was below the critical value of .70).

The factor structure of the Polish adaptation of the CISS is consistent with the theoretical assumptions of the measure. This was confirmed by the factor analysis, which identified three factors positively correlating with the three scales of the questionnaire: (1) Factor 1, which explained $13.8 \%$ of the variance 
in TFS scores, (2) Factor 2, which explained 9.8\% of the variance in EFS scores, and (3) Factor 3, explaining $8.1 \%$ of the variance in AFS scores.

The SCQ is a self-report tool which measures a person's social skills based on various activities and events. The examined person assesses the effectiveness with which they manage situations using a four-level scale, from 1 -definitely poorly to 4 -definitely well. The test consists of 90 items; 60 of these are diagnostic and the remaining 30 refer to the subject's non-social skills - the latter are not taken into account when calculating the score. Apart from the general score on social competences, the diagnostic items form three separate scales measuring different types of skills: (1) social competences in intimate situations (IN); (2) social competences in social exposure situations (SE); (3) social competences in situations requiring assertiveness (AS). The scores on three subscales are calculated by summing up the item scores, and the overall score on social competence is a sum of the scores for all 60 diagnostic items.

According to results reported by Matczak (2007), the reliability of the SCQ is acceptable. Cronbach's alpha coefficients for the Social Exposition and Assertiveness scales exceed $.80(\alpha=.92$ for SE; $\alpha=.84$ for AS). The exception was the Intimacy scale $(\alpha=.81)$. The factorial analysis confirmed the presence of three factors corresponding to the scales of the questionnaire.

\section{Procedure}

A pencil-and-paper questionnaire consisting of the scales described above was administered to groups of around 25 people. The research was carried out before the beginning of selected theory of music classes, attended by both classical and jazz students. It took the students about 30 minutes to complete the questionnaire. Participation in the research was voluntary and anonymous.

We used Statistica (STAT) version 13 to calculate the results. The analysis consisted of descriptive statistics computed for each group of musicians and independent samples $t$-tests.

\section{RESULTS}

We performed Shapiro-Wilk's tests of normality to check if the variables were normally distributed. The results show normal distributions of scores on the CISS and SCQ subscales, except the TFS scale, for which the Shapiro-Wilk test was significant, $W=0.97, p=.05$. However, given that in this single case the 
$p$ value was exactly equal to .05 , we assumed that the obtained data allows for conducting further analysis with parametric statistics.

To sum up the data on stress coping styles and social skills in classical and jazz musicians, we computed descriptive statistics. The means $(M)$, standard deviations $(S D)$ for all variables in both groups are presented in Table 1.

Table 1. Means, Standard Deviations, and Independent Samples t-Test Scores for Stress Coping Styles and Social Skills in Samples of Classical $(\mathrm{n}=38)$ and Jazz Musicians $(\mathrm{n}=35)$

\begin{tabular}{|c|c|c|c|c|c|c|}
\hline & \multirow{2}{*}{ VARIABLES } & \multirow{2}{*}{$\begin{array}{l}\text { MUSICIANS' } \\
\text { SPECIALTY }\end{array}$} & \multirow{2}{*}{$M$} & \multirow{2}{*}{$S D$} & \multicolumn{2}{|c|}{ For all musicians } \\
\hline & & & & & $t$ & $p$ \\
\hline \multirow{10}{*}{ 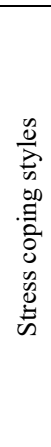 } & \multirow{2}{*}{ TASK-focused style } & Classical & 57.87 & 10.26 & \multirow{2}{*}{-0.38} & \multirow{2}{*}{.70} \\
\hline & & Jazz & 58.77 & 9.79 & & \\
\hline & \multirow{2}{*}{ EMOTION-focused style } & Classical & 45.11 & 10.02 & \multirow{2}{*}{-0.14} & \multirow{2}{*}{.89} \\
\hline & & Jazz & 45.43 & 9.27 & & \\
\hline & \multirow{2}{*}{$\begin{array}{l}\text { AVOIDANCE-focused } \\
\text { style }\end{array}$} & Classical & 44.16 & 7.77 & \multirow{2}{*}{-0.69} & \multirow{2}{*}{.49} \\
\hline & & Jazz & 45.63 & 10.25 & & \\
\hline & \multirow{2}{*}{ DISTRACTION } & Classical & 19.21 & 5.30 & \multirow{2}{*}{-0.59} & \multirow{2}{*}{.56} \\
\hline & & Jazz & 19.97 & 5.68 & & \\
\hline & \multirow{2}{*}{ SOCIAL DIVERSION } & Classical & 16.92 & 3.68 & \multirow{2}{*}{-0.19} & \multirow{2}{*}{.85} \\
\hline & & Jazz & 17.09 & 3.58 & & \\
\hline \multirow{8}{*}{$\begin{array}{l}\frac{n}{\bar{\sigma}} \\
\frac{\vec{v}}{\omega} \\
\frac{\vec{\pi}}{d} \\
\dot{0}\end{array}$} & \multirow{2}{*}{ OVERAL SCORE } & Classical & 168.87 & 26.79 & \multirow{2}{*}{-1.61} & \multirow{2}{*}{.12} \\
\hline & & Jazz & 178.54 & 24.30 & & \\
\hline & \multirow{2}{*}{ Intimacy } & Classical & 42.71 & 6.43 & \multirow{2}{*}{-0.35} & \multirow{2}{*}{.73} \\
\hline & & Jazz & 43.26 & 6.86 & & \\
\hline & \multirow{2}{*}{ Social exposure } & Classical & 50.32 & 10.24 & \multirow{2}{*}{-2.13} & \multirow{2}{*}{.04} \\
\hline & & Jazz & 55.20 & 9.31 & & \\
\hline & \multirow{2}{*}{ Assertiveness } & Classical & 45.26 & 8.64 & \multirow{2}{*}{-1.88} & \multirow{2}{*}{.06} \\
\hline & & Jazz & 48.69 & 6.69 & & \\
\hline
\end{tabular}

The analysis showed that musicians representing both genres mostly used a task-focused style of coping with stress and less often resorted to avoidant or emotion focused strategies. ${ }^{2}$ Their AFS and EFS levels were similar, suggesting that they used avoidant and emotion-focused strategies similarly often. Of three SCQ subscales (AS, SE, IN), the mean scores on SE scale were the highest, AS

${ }^{2}$ This is only an approximate comparison; we did not conduct statistical tests to compare average scores on CISS or SCQ subscales. 
mean scores were lower, and the mean scores on the IN scale were the lowest. This suggests that musicians cope with tasks involving social exposure better than, for example, with tasks requiring assertiveness or in intimate situations.

To determine whether and what differences occurred between classical and jazz musicians in terms of coping with stress and social skills, we performed further analysis using independent samples $t$-tests. As can be seen in Table 1, the results of the analysis did not show any significant differences in any of the stress coping styles. In both groups of musicians, the level of the emotionoriented stress coping style was very similar. Other styles were higher in jazz musicians, but these are not statistically significant differences.

Significant differences between musician groups were noted in the field of social skills. Jazz musicians displayed higher competence in public exposure situations than classical musicians, which means they might be much better at dealing with the situation of a public performance. In other dimensions of social competence, including the overall score, no significant differences were found between classical and jazz musicians (although the difference in assertiveness was nearly significant).

\section{DISCUSSION AND CONCLUSION}

Our analysis provided an answer to the research question about the differences in stress coping styles and social skills between musicians specializing in classical and jazz music. Jazz musicians demonstrated higher social exposure skills, which means that, compared to classical musicians, they better cope with situations involving public exposure, such as musical performance. This may be due to both lower experience of stress and more frequent performances in front of audiences (Benedek et al., 2014). Studies from other psychological subdisciplines confirm that people with high social skills receive more support from the environment, which allows for more effective ways of dealing with stress (Cohen, Sherrod, \& Clark, 1986; Strelau et al., 2005).

Surprisingly, there were no differences between the examined group of musicians in the use of selected coping styles. It was expected that, due to lower performance anxiety (Papageorgi et al., 2013), jazz musicians would exhibit a significantly lower level of less effective (i.e., emotion-focused, avoidance-focused) coping styles than classical musicians and a higher level of the more effective (i.e., task-focused) coping style. The lack of marked differences between the groups of classical and jazz musicians may result from certain limitations of this 
study. Firstly, the groups were relatively small. Secondly, they differed with regard to mean age, and gender equivalence were not perfect. These limitations may have resulted in the lack of differences between the groups.

In conclusion, jazz musicians might have a higher level of social skills related to social exposure. But it is difficult to judge whether this stems from the music genre itself or from the specificity of classical or jazz music education. The results of the current investigation invite further research, which will examine new variables and yield a better understanding of the psychosocial profiles of musicians representing various specialties.

As in this study we only compare the level of coping between groups, it remains for future studies to explain, for example, why musicians differ in terms of social skills. The important question to answer is to what extent the temperament and personality of musicians of different specialties influence their level of stress, their strategies of coping with stress, and their social skills (see Kemp, 1996; Nogaj, 2018). Are the differences in social skills a result of personal dispositions (such as temperament) or of the specific music genre being performed? It would also be worth considering the mediating role of social support received by musicians during the education process. Support is often perceived as an elementary dimension of an individual's social functioning, shaping attitudes and ways of dealing with difficulties (see Nogaj \& Ossowski, 2015).

The results of the present study also provoke some practical suggestions for budding musicians, which will give them a better understanding of their psychological functioning. First of all, it is worth emphasizing that musicians differ significantly from non-musicians in a number of dimensions; these differences, however, are not unusual deviations from the standards, but rather indicate a different level of functioning, for instance in terms of resistance to stress, social skills, emotional intelligence, or self-esteem (see Kemp, 1996; Auslander, 2006; Creech et al., 2008; Hallam, 2008). Although the present study focused on a small group of musicians - representatives of only two specialties - it revealed some characteristic tendencies in the area of social skills. However, the higher level of social exposure skills in jazz-trained musicians does not prove that classical musicians in general have lower skills in this area. But it is worth underlining that the free performance style in jazz musicians can make it easier for them to function on stage. The results of the study might be an inspiration for psychologists working with musicians to plan therapeutic programs in aimed at psychological preparation for public performances, taking into account the nature of the music performed by representatives of various musical genres. 
Music is an extremely colorful and diverse phenomenon, and so is the functioning of performing artists. In addition to the individual characteristics of all people, instrumentalists specializing in a particular musical genre follow certain fads and adhere to certain canons of behavior that may shape their specific mode of functioning. This fact is proven in a growing number of psychological tests indicating significant differences not only between representatives of various musical genres, but also between instrumentalists of particular specialties, as well as vocalists, composers, and conductors. Each musical specialty is a separate activity requiring a range of narrow skills.

\section{REFERENCES}

Altenmüller E., \& Furuya, S. (2016). Planning and performance. In S. Hallam, I. Cross, \& M. Thaut (Eds.), The Oxford handbook of music psychology (pp. 529-545). New York, NY, US: Oxford University Press.

Argyle, M. (1991). Psychologia stosunków międzyludzkich [The psychology of interpersonal relations] (W. Domachowski, Trans.). Warsaw, Poland: Wydawnictwo Naukowe PWN.

Auslander, P. (2006). Musical personae. The Drama Review, 50(1), 100-119.

Bastien, D. T., \& Hostager, T. J. (1988). Jazz as a process of organizational innovation. Communication Research, 15, 582-602. DOI:10.1177/009365088015005005

Benedek, M., Borovnjak, B., Neubauer, A. C, \& Kruse-Weber, S. (2014). Creativity and personality in classical, jazz and folk musicians. Personality and Individual Differences, 63(100), 117-121. DOI:10.1016/j.paid.2014.01.064

Berliner, P. F. (1994). Thinking in jazz. The infinite act of improvisation. Chicago, IL, US, \& London, UK: University of Chicago Press.

Bézenak, C., \& Swindells, R. (2009). No pain, no gain? Motivation and self-regulation in music learning. International Journal of Education \& the Arts, 10(16), 1-33.

Białkowski, A. (2013). Wstęp. Edukacja w dziedzinie jazzu i muzyki estradowej. Potrzeba, zakres i projekt diagnozy [Introduction. Education in the field of jazz and stage music. Need, scope, and design of assessment]. In A. Białkowski (Ed.), Edukacja w dziedzinie jazzu i muzyki estradowej $w$ Polsce [Education in the field of jazz and stage music in Poland] (pp. 7-14). Warsaw, Poland: Instytut Muzyki i Tańca.

Bissinger-Ćwierz, U., \& Nogaj, A. A. (2018). Strategie radzenia sobie z trema $w$ kształceniu muzycznym oraz $w$ zawodzie muzyka [Strategies for coping with stage fright in music education and the music profession]. Warsaw, Poland: Difin.

Brackett, M. A., Mayer, J. D., \& Warner, R. (2004). Emotional intelligence and its relation to everyday behaviour. Personality and Individual Differences, 36(6), 1387-1402. DOI: 10.1016/S01918869(03)00236-8

Brands, I. M. H., Köhler, S., Stapert, S. Z., Wade, D. T., \& van Heugten, C. M. (2014). Psychometric properties of the Coping Inventory for Stressful Situations (CISS) in patients with acquired brain injury. Psychological Assessment, 26(3), 848-856. DOI:10.1037/ a0036275 
Chłoń-Domińczak, A., Sławiński, S., Kraśniewski, A., \& Chmielecka, E. (2017). Polska Rama Kwalifikacji [Polish Qualifications Framework]. Warsaw, Poland: Instytut Badań Edukacyjnych (The Educational Research Institute).

Cohen, S., Sherrod, D. R., \& Clark, M. S. (1986). Social skills and the stress-protective role of social support. Journal of Personality and Social Psychology, 50(5), 963-973. DOI: 10.1037//0022-3514.50.5.963

Creech, A., Papageorgi, I., Duffy, C., Morton, F., Hadden, E., Potter, J., De Bezenac, Ch., Whyton, T., Himonides, E., \& Welch, G. (2008). Investigating musical performance: Commonality and diversity among classical and non-classical musicians. Music Education Research, 10(2), 215-234. DOI:10.1080/14613800802079080

Davidson, J. W. (2007). Bodily communication in musical performance. In D. Miell, R. MacDonald, \& D. J. Hargreaves (Eds.), Musical communication (pp. 215-237). OxfordNew York, NY, US: Oxford University Press.

Davidson, J. W. (2009). The solo performer's identity. In R. MacDonald, D. Hargreaves, \& D. Miell (Eds.), Musical identities (pp. 97-113). New York, NY, US: Oxford University Press.

Dobson, M. C. (2010). Performing your self? Autonomy and self-expression in the work of jazz musicians and classical string players. Music Performance Research, 3(1), Special Issue: Music and Health, 42-60.

Endler, N. S., \& Parker, J. D. A. (1990). Multidimensional assessment of coping: A critical evaluation. Journal of Personality and Social Psychology, 58, 844-854.

Gaunt, H., \& Hallam, S. (2009). Individuality in the learning of musical skills. In S. Hallam, I. Cross, \& M. Thaut (Eds.), The Oxford handbook of music psychology (pp. 274-284). New York, NY, US: Oxford University Press.

Hallam, S. (2008). Music psychology in education. London: Bedford Way Papers.

Jankowski, W. (2002). Polskie szkolnictwo muzyczne. Geneza i ewolucja systemu [Polish music education. Genesis and evolution of the system]. Warsaw, Poland: Akademia Muzyczna im. F. Chopina, Centrum Edukacji Artystycznej.

Jaślar-Walicka, E. (1999). Różne modele nauczycieli w przebiegu edukacji muzycznej w świetle badań amerykańskich i polskich nad muzykami i talentami muzycznymi [Different models of teachers in the course of music education in the light of American and Polish research on musicians and musical talents]. In M. Manturzewska (Ed.), Psychologiczne podstawy ksztatcenia muzycznego [Psychological foundations of musical education] (pp. 163-170). Warsaw, Poland: Akademia Muzyczna im. F. Chopina.

Johnson-Laird, P. N. (2002). How jazz musicians improvise. Music Perception, 19(3), 415-442. DOI:10.1525/mp.2002.19.3.415

Kantor-Martynuska, J., \& Domaradzka, E. (2018). Performance anxiety: The need for an integrative approach. Polish Psychological Bulletin, 49(3), 272-282. DOI:10.24425/119495

Kemp, A. E. (1996). The musical temperament. Psychology and personality of musicians. New York, NY, US: Oxford University Press.

Kenny, B. J., \& Gellrich, M. (2002). Improvisation. In R. Parncutt, \& G. E. McPherson (Eds.), The science and psychology of music performance. Creative strategies for teachers and learning (pp. 117-134). New York, NY, US: Oxford University Press.

Kenny, D. T. (2011). The psychology of music performance anxiety. New York, NY, US: Oxford University Press. 
Klickstein, G. (2009). The musician's way. A guide to practice, performances, and wellness. New York, NY, US: Oxford University Press.

Lazarus, R., \& Folkman, S. (1984). Stress, appraisal, and coping. New York, NY, US: Springer.

Lehmann, A., Sloboda, J. A., \& Woody, R. H. (2007). Psychology for musicians. Understanding and acquiring the skills. New York, NY, US: Oxford University Press.

Lemański, P. (2013). Średnie szkolnictwo jazzowe i rozrywkowe [Secondary jazz and entertainment schools]. In A. Białkowski (Ed.), Edukacja $w$ dziedzinie jazzu i muzyki estradowej $w$ Polsce [Education in the field of jazz and stage music in Poland] (pp. 57-67). Warsaw, Poland: Instytut Muzyki i Tańca.

MacDonald, R. A. R., Hargreaves, D. J., \& Miell, D. (2009). Musical identities. In S. Hallam, I. Cross, \& M. Thaut (Eds.), The Oxford handbook of music psychology (pp. 462-470). New York, NY, US: Oxford University Press.

MacDonald, R. A. R., \& Wilson, G. B. (2005). The musical identities of professional jazz musicians: A focus group investigation. Psychology of Music, 33(4), 395-419.

Manturzewska, M. (2014). Psychologiczne wyznaczniki powodzenia w studiach muzycznych [Psychological determinants of success in music studies]. Warsaw, Poland: Centrum Edukacji Artystycznej, Uniwersytet Muzyczny Fryderyka Chopina.

Matczak, A. (2001a). Różne oblicza inteligencji: funkcjonowanie intelektu a osobowość [Different faces of intelligence: The functioning of the intellect and personality]. Studia Psychologica, 2, $157-174$.

Matczak, A. (2001b). Temperament a kompetencje społeczne [Temperament and social skills]. In W. Ciarkowska \& A. Matczak (Eds.), Różnice indywidualne: wybrane badania inspirowane Regulacyjna Teoria Temperamentu Profesora Jana Strelaua [Individual differences: Selected studies inspired by Professor Jan Strelau's Regulatory Theory of Temperament] (pp. 53-69). Warsaw, Poland: Interdyscyplinarne Centrum Genetyki Zachowania.

Matczak, A. (2007). Kwestionariusz Kompetencji Społecznych KKS. Podręcznik [Social Competence Questionnaire KKS. A manual]. Warsaw, Poland: Psychological Test Laboratory of the Polish Psychological Association.

McPherson, G. E., \& Schubert, E. (2004). Measuring performance enhancement in music. In A. Williamon (Ed.), Musical excellence. Strategies and techniques to enhance performance (pp. 61-82). New York, NY, US: Oxford University Press.

Nogaj, A. A. (2018). Temperament i kompetencje społeczne charakteryzujące uczniów szkół artystycznych w okresie późnej adolescencji [Temperament and social skills of artistic school students in late adolescence]. Psychologia Rozwojowa, 23(1), 69-88. DOI:10.4467/20843879 PR.18.004.8599

Nogaj, A. A., \& Ossowski, R. (2015). Social support as a mediator for musical achievement. Polish Psychological Bulletin, 46(2), 300-308. DOI:10.1515/ppb-2015-0036

Papageorgi, I., Creech A., \& Welch, G. (2013). Perceived performance anxiety in advanced musicians specializing in different musical genres. Psychology of Music, 41, 18-41. DOI:10.1177/0305735611408995

Parasuraman, S., \& Purohit, Y. S. (2000). Distress and boredom among orchestra musicians: The two faces of stress. Journal of Occupational Health Psychology, 5(1), 74-83. DOI:10.1037/1076-8998.5.1.74

Parker, J. D. A., \& Endler, N. S. (1992). Coping with coping assessment: A critical review. European Journal of Personality, 6, 321-344. DOI: https://doi.org/10.1002/per.2410060502 
Perdomo-Guevara, E. (2014). Is music performance anxiety just an individual problem? Exploring the impact of musical environments on performers' approaches to performance and emotions. Psychomusicology: Music, Mind, and Brain, 24(1), 66-74. DOI: 10.1037/pmu0000028

Smółka, P. (2016). Kompetencje społeczne: Metody pomiaru i doskonalenia umiejętności interpersonalnych [Social skills: Methods of measuring and improving interpersonal skills]. Warsaw, Poland: Wydawnictwo Wolters Kluwer.

Steptoe, A. (1989). Stress, coping and stage fright in professional musicians. Psychology of Music, 17, 3-11. DOI:10.1177/0305735689171001

Steptoe, A. (2001). Negative emotions on music making: The problem of performance anxiety. In P. N. Juslin \& J. A. Sloboda (Eds.), Music and emotions (pp. 291-308). Oxford, UK: Oxford University Press.

Stoeber, J., \& Eismann, U. (2007). Perfectionism in young musicians: Relations with motivation, effort, achievement, and distress. Personality and Individual Differences, 43, 2182-2192. DOI:10.1016/j.paid.2007.06.036

Strelau, J., Jaworowska, A., Wrześniewski, K., \& Szczepaniak, P. (2005). Kwestionariusz Radzenia Sobie $w$ Sytuacjach Stresowych CISS. Podręcznik [The Coping Inventory for Stressful Situations (CISS). A manual]. Warsaw, Poland: Psychological Test Laboratory of the Polish Psychological Association.

Welch, G., \& Ockelford, A. (2009). The role of the institution and teachers in supporting learning. In S. Hallam, I. Cross, \& M. Thaut (Eds.), The Oxford handbook of music psychology (pp. 307-319). New York, NY, US: Oxford University Press.

Wilson, G. B., \& MacDonald, R. A. R. (2005). The meaning of the blues: Musical identities in talk about jazz. Qualitative Research in Psychology, 2, 341-363. DOI: 10.1191/1478088705 qp044oa

Williamon, A. (2004). Musical excellence. Strategies and techniques to enhance performance. New York, NY, US: Oxford University Press. 